\title{
Basil oil nanoemulsion formulation and its antimicrobial activity against fish pathogen and enhance disease resistance against Aeromonas hydrophila in cultured Nile tilapia
}

\author{
Walaa T. El-Ekiaby
}

Department of Fish Health and Management, Central Laboratory for Aquaculture Research, Agricultural Research Center, Egypt.

Received: Oct. 22, 2019; Accepted: December. 27, 2019 published: 2019 Vol.9 (4):13-32

\section{ABSTRACT}

Pure basil oil which has antimicrobial and immunostimulant effect in the cultured fish was formulated into nanoemulsion using homogenizer. Basil oil nanoemulsion characters, its effect as antimicrobial in vitro and its resistant against Aeromonas hydrophila were studied. The results revealed that the droplet size distribution of the basil oil nanoemulsion measured $6.419 \mathrm{~nm}$ in diameter with poly dispersity index (PDI) value 0.753 , Zeta potential $-1.01 \mathrm{mV}, \mathrm{pH}$ value 5.55 , the conductivity $203.5 \mu \mathrm{S} / \mathrm{m}$ and the viscosity $0.887 \mathrm{mpascal} / \mathrm{sec}$. Basil oil nanoemulsion had antibacterial effect at $6 \mu 1$ concentration against Aeromonas hydrophila, Aeromonas veronii, Pseudomonas fluorescens and Streptococcus agalactiae while, at $3 \mu 1$ concentration had antifungal effect against Saprolegnia parasitica. Minimum inhibitory concentration (MIC) of this formulation of basil oil differ among the examined bacterial isolated from 3-9 $\mu$ l. Basil oil nanoemulsion save for Oreochromis niloticus at $8.5 \%$ of fish body weight for 14 days and increased fish resistance. Moreover, basil oil nanoemulsion showed different effects against $A$. hydrophila by using ultrastructure electron microscope which were discussed in this study.

Key words: Basil oil, nanomulsion, bacteria, fungus, antimicrobial, MIC mode of action, disease resistance. 


\section{INTRODUCTION}

Fish aquaculture constitutes a rapidly growing industry worldwide. This has led to a concomitant increase in aquaculture intensity methods, which increase the susceptibility to disease outbreaks and the necessity use of the medicated diet Jerbi et al., (2011).

The pathogenic diseases are one of the frequent problems occurring in modern aquaculture system. Various chemotherapeutic agents such as antibiotics and disinfectants have been traditionally used in the treatment and prevention of numerous diseases in farmed fish. However, they cannot be recommended since improper and continuous use of antibiotics may lead to potential development of antibiotic resistant bacteria, environmental pollution and the accumulation of residues in fish Syahidah et al., (2015).

Herbs and medicinal plants are promising to be an important source of therapeutics in fish culture Madhuri et al., (2012). In general, plants have a variety of functions due to the presence of various active compounds like alkaloids, flavanoids, pigments, phenolics, terpenoids, steroids and essential oils Citarasu (2010).

Ocimum basilicum essential oils and their principal constituents were found to exhibit antimicrobial activity against a wide range of Gram-negative and Gram-positive bacteria, yeast and mold.

Nanotechnology is the science that largely deals with synthesis and application of nano size particles ranging from (1-100 nm). Advancement of nanoscience and nanoscale techniques in recent times holds the promise of better stability, best control and antimicrobial activity Suresh et al., (2013).

Bio-nanotechnology is a new branch of nanotechnology which is using biological agents such as microbes or plant extracts in biosynthesis of nanoparticles, it has gained much attention in the area of nanotechnology in last few decades Malik et al., (2014).

Emulsions are used to stabilize and increase the antimicrobial efficacy of oils in aqueous solutions, when this emulsion system tends to reach nanometric size; it is called "nanoemulsion" Echeverría and Albuquerque (2019).

Since the 1980's, attention has been focused on emulsions with droplet size in the nanometer range (nanoemulsions) which have some individual characteristics, such as transparency when viewed by the 
naked eye, and a bluish reflection may be observed, due to the diffusion of light between the nanoparticles, which is known as the Tyndall effect Salager et al., (2001).

In general, nanoemulsions contain oil in their outer shell layer and a core portion inside health promoting compounds, where in nanoemulsions are relatively stable for prolonged periods without significant changes in their physical properties. The fundamental oil based nanoemulsions shows higher antimicrobial efficacy as compared to the pure oil because of their increased surface area and small droplet size Pathania et al., (2018).

So, the present work aimed to study basil oil nanoemulsion formulation and its antimicrobial activity against fish pathogen in cultured Nile tilapia.

\section{MATERIALS AND METHODS}

\section{Basil oil (Ocimum basilicum oil):}

Basil oil were obtained from the Medicinal and Aromatic Plants Section at El-Kanater El-Khairia, Kalubia Governorate, Hort. Res. Institute, A.R.C. Basil oil extracted through steam distillation for 3 hours using a Clevenger-type apparatus according to Angioni et al., (2006).

\section{Basil oil nanoemulsion formulation:}

Nanoemulsion was formulated using basil oil, non-ionic surfactant Tween80 (Polyoxyethylene (20) Monooleate) obtained from (United Company for Chem. \& Med. Prep., Cairo, Egypt) and water. Nanoemulsion was prepared with some modifications using 1 part of basil oil to 3partsTween 80according to Ghosh et al., (2013) and slowly adding distilled water till $100 \mathrm{ml}$ with gentle agitation using a magnetic stirrer for 45 minutes. Then the emulsion was subjected to a homogenizer (Wise Tis ${ }^{\circledR}$ homogenizer HG-15A; Daihan Scientific, Co., Ltd., Seoul, Korea),70.000 rpm for 30 minutes with stopping every five minutes placing the sample container in a bigger beaker containing ice to avoid generated heat during the prolonged process of emulsification according to Anjali et al., (2010).

\section{Characterization of basil oil nanoemulsion:}

All the characterization process was done in room temperature $25 \pm 0.5^{\circ} \mathrm{C}$ and in Nanotechnology and Advanced Material Central Lab (NAMCL), Regional Center for Food \& Feed (RCFF), Agricultural 
Research Center (ARC), Giza, Egypt. Droplet size and polydispersity index (PDI) were measured by dynamic light scattering (DLS) technique according to Sugumar et al., (2014) using particle size analyzer (Malvern-UK, 4700). Zeta potential was determined using Zeta sizer nano series (Nano ZS) 3000HSA (Malvern-UK, 4700). The $\mathrm{pH}$ value and conductivity of basil oil nanoemulsion were measured using (Orion 5 star series, thermo electron corporation, USA) at room temperature according to Shafiq et al., (2007). The viscosity of basil oil nanoemulsion was measured by Ostwald viscometer performed at a temperature of $25 \pm 0.5$ ${ }^{\circ} \mathrm{C}$, experiments were performed in triplicate according to Abbas et al., (2010). Thermodynamic stability of basil oil nanoemulstion was checked by storing it independently at $25^{\circ} \mathrm{C}$ and $4{ }^{\circ} \mathrm{C}$ for a month. In addition, the basil oil nanoemulsion was subjected to centrifugation at $10,000 \mathrm{rpm}$ for $30 \mathrm{~min}$, and then was observed for any creaming, phase separation, or cracking according to Ghosh et al., (2013).

\section{Antimicrobial activity of basil oil nanoemulsion:}

\section{Microorganisms:-}

\section{Bacterial strains, culture conditions and preparation of inoculums:}

Bacterial isolates used in this study were Gram negative bacteria (Aeromonas hydrophila, Aeromonas veronii and Pseudomonas fluorescens) and Gram positive bacteria (Streptococcus agalactiae) were kindly supplied from Fish Diseases Dept., Central Laboratory for Aquaculture Research, El-Abbassa, Egypt. The bacterial isolates previously isolated from diseased $O$. niloticus and confirmed its identification using API20E strips for gram-negative bacterial isolates while, Gram positive confirmed using Gram-stain, cocci shape and arranged in strep under microscope. All bacterial cells were grown and maintained on slants of tryptic soya agar (TSA), (Difco Laboratories, Becton, Dickinson and Company, Sparks, MD, USA) and stored at $4{ }^{\circ} \mathrm{C}$ until needed.

Prior to the experiment, 3 consecutive transfers of the bacterial cultures were inoculated in tryptic soya broth (Difco Lab., Becton, Dickinson and Co.). The cultures were incubated overnight at $30^{\circ} \mathrm{C}$, then the inoculums were standardized according to a McFarland 0.5 turbidity standard $\left(10^{8}\right.$ cells/ $\left.\mathrm{ml}\right)$ by diluting the samples with the broth NCCLS (2004). Culture growth turbidity, which indicated by the Optical Density (OD), was adjusted to a specific rate for each type of bacteria at a wavelength of $550 \mathrm{~nm}$ (OD550), using the spectrophotometer, (UV/VIS 
Spectrophotometer model, Perkin-Elmer, lambda 3B) to the final concentrations of $10^{8}$ cells $/ \mathrm{ml}$.

\section{Fungi isolate, culture and preparation of inoculum:}

One species of fungi Saprolegnia parasitica kindly supplied from Fish Diseases Dep. CLAR which previously isolated from diseased $O$. niloticus for the antifungal activity of basil oil nanoemulsion test. Fungal isolate was confirmed by mount preparation from culture on Sabouraud's Dextrose agar and see hyphen under the microscope. Sabouraud's Dextrose agar medium with antibiotics Chloramphenicol (50ppm) for $48 \mathrm{~h}$ with not defined amount of Saprolegnia parasitica was used for antifungal test of basil oil nanoemulsion.

\section{Antibacterial activity of basil oil nanoemulsion:}

The antibacterial activity of basil oils nanoemulsion was evaluated by agar disc diffusion method Murray et al., (2007). Briefly, the test was performed in sterile Petri dishes (100 mm diameter) contained sterile tryptic soya agar medium. Basil oil nanoemulsion was used in two doses $(0.05$ and $0.1 \mathrm{ml})$ which had $(0.003$ and $0.006 \mathrm{ml}$ concentration of basil oil) absorbed on sterile filter paper discs (6 mm diameter) and placed on the surface of the media previously inoculated with tryptic soya broth contained the examined bacteria at $10^{5} / \mathrm{ml}$. another discs were used as control (one adsorbed with sterile distilled water (control negative) and the other with $0.1 \mathrm{ml}$ of pure basil oil (control positive)) each bacterial isolate was tested in three replicates and incubated at $30^{\circ} \mathrm{C}$ for $48 \mathrm{~h}$. Antibacterial activity was evaluated by measuring the diameter of the inhibition zones expressed in mm against the tested bacteria.

\section{Antifungal activity of basil oil nanoemulsion:}

Hollow well technique (agar-well) was used for antifungal activity of basil oil nanoemulsion against Saprolegnia parasitica. Sabouraud's Dextrose agar with Chloramphenicol $(50 \mathrm{ppm})$ to inhibit saprophytic bacteria was poured in sterile Petri dishes. After solidification $1 \mathrm{ml}$ of freshly live fungus in Sabouraud's Dextrose broth was inoculated and after dryness four holes were punched into the agar $(5 \mathrm{~mm}$ diameter) where not reached the dish bottom. The holes were filled with $100 \mu \mathrm{l}$ sterile distilled water (control negative) in one hole, $100 \mu 1$ pure basil oil (control positive) in the second hole, 50 and $100 \mu \mathrm{l}$ of basil oil nanoemulsion $(0.003$ and $0.006 \mathrm{ml}$ concentration of basil oil in the nanoemulsion) in the other two holes. The plates were incubated for 2 days at $28^{\circ} \mathrm{C}$ and inhibition zones diameter $(\mathrm{mm})$ were measured. 


\section{Minimal Inhibition Concentration (MIC):}

Broth micro-dilution method was used to determine Minimal Inhibition Concentration (MIC) of basil oil nanoemulsion against the examined bacterial isolates Aeromonas hydrophila, Aeromonas veronii, Pseudomonas fluorescens and Streptococcus agalactiae according to Yu et al., (2004).

For each bacterial isolates one test tube contained $2 \mathrm{ml}$ and other eight tubes $1 \mathrm{ml}$ of sterilized tryptic soy broth. In the first tube, $0.3 \mathrm{ml}$ of tryptic soya broth was removed and replaced by $0.3 \mathrm{ml}$ of basil oil nanoemulsion and mixed thoroughly. Then, a serial dilution was occurred to all tubes with removing one $\mathrm{ml}$ of the last tube. The ninth tube contained tryptic soya broth free from basil oil emulsion as control negative. All tubes were inoculated with $10^{2}$ cells from each examined bacterial isolates and incubated at $30^{\circ} \mathrm{C}$ for $24 \mathrm{~h}$. A loopfull from each tube was inoculated into tryptic soya agar and incubated at $30^{\circ} \mathrm{C}$ for $24 \mathrm{~h}$ and tested for bacterial culture growth at the least basil oil nanoemulsion concentration, which did not show any visible growth of test organisms MICs, expressed in $\mu \mathrm{g} / \mathrm{ml}$.

\section{Mode of action of Basil oil nanoemulsion as antibacterial against Aeromonas hydrophila:}

The isolated Aeromonas hydrophila strain was sub-cultured in tryptic soy broth and incubated for $18 \mathrm{~h}$ at $30^{\circ} \mathrm{C}$. After incubation bacterial culture was centrifuged $(3,000 \mathrm{rpm}$ for 15 minutes) to get rid of the supernatants and bacterial precipitates were collected for electron microscope technique. The collected bacterial pellets were fixed for 24 hours (minimum) in $3 \%$ glutaraldehyde buffered with $0.15 \mathrm{M} \mathrm{Na}$ cacodylate $\mathrm{pH}$ 7.2. Following 3 rinses in cacodylate buffer, the pellets were post fixed in $1 \%$ osmium tetroxide for 4 hours at room temperature. The pellets were rinsed in buffer and dehydrated through a graded series of ethanol, before embedding samples were suspended in a 1/1 mixture of propylene oxide and epoxy resins for 2 hours. The pellets were infiltrated with full strength resin for 8 hours prior to embedding in epoxy resin and polymerization in oven at $60^{\circ} \mathrm{C}$ for $48 \mathrm{~h}$, then thin sections of the pellets were cut with glass knives of the used ultra-microtome. Thin sections were retrieved on uncoated copper specimen grids after which they were post stained for $15 \mathrm{~min}$. with $5 \%$ uranyl acetate and for $2 \mathrm{~min}$. with $4 \%$ lead citrate. Ultrathin sections were examined, viewed, photographed with transmission electron microscope and observed at $80 \mathrm{kV}$ using 
(JEOL-TME-2100F, Japan) at the Electron Microscopy Unit, Mansoura University, Mansoura, Egypt, according to Kinner et al.,(1983).

\section{Safety of basil oil nanoemulsion for Oreochromis niloticus:}

Total 150 apparently health Oreochromis niloticus fry ( $4 \pm 0.5$ gm body weight) collected from Central Laboratory for Aquaculture Research Center Reproduction part and transported into Fish Health wet lab. After acclimatization for two weeks fish divided into two groups, the first group 75 fish in three replicates fed diet contained basil oil emulsion $8.5 \%$ of fish body weight per day (32\% crude protein) and the other fish group fed normal diet as control. Fish fed $7 \%$ of body weight twice per day for 14 days. Fish was recorded to any mortality, morbidity or any abnormalities.

\section{Challenge test:}

At the end of feeding experiment fish divided into two subgroups, each subgroup in three replicates (10 fish per replicate). One subgroup from the two groups were challenged by emersion with A. hydrophila $24 \mathrm{~h}$ live at $10^{8}$ cells $/ \mathrm{ml}$ saline for $15 \mathrm{~min}$. challenged fish were recorded for 10 days for mortality or morbidity and re-isolation of $A$. hydrophila was occurred. The relative level of protection (RLP) was determined according to Ruangroupan et al., (1986).

$\mathrm{RLP}=[1-\quad$ (number of treated mortality/number of control mortality) $] \times 100$.

\section{Statistical analysis:}

The data were analyzed by comparing the means differences using analysis of variance (One Way ANOVA) using SPSS program version 20 (SPSS, Richmond, VA, USA) as described by Dytham (1999).

\section{RESULTS}

\section{Basil oil nanoemulsion Charazterization:}

The droplet size distribution of the basil oil nanoemulsion measured $6.419 \mathrm{~nm}$ in diameter as showed in Figure (1) and polydispersity index (PDI) 0.753.Zeta potential of basil oil nanoemulsion was negative charge $1.01 \mathrm{Mv}$ Figure (2). The $\mathrm{pH}$ value of the basil oil nanoemulsion was 5.55, the conductivity $(203.5 \mu \mathrm{S} / \mathrm{m})$ and the viscosity $0.887 \mathrm{mpascal} / \mathrm{sec}$. There was no observed sign of instability of the nanoemulsion, including phase separation or creaming, it was stable after centrifugation at 10,000 rpm for $30 \mathrm{~min}$ and also it was stable when stored for a month at $4^{\circ} \mathrm{C}$. 


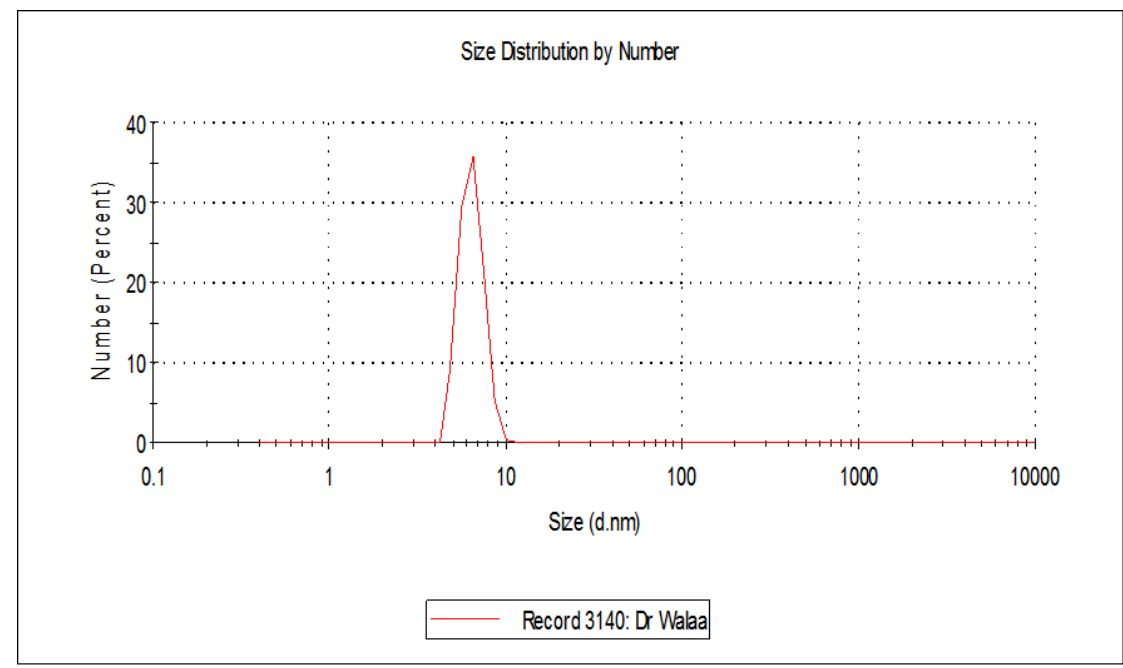

Figure (1): Droplet size distribution by number of basil oil nanoemulsion. Basil oil nanoemulsion droplet size was $6.419 \mathrm{~nm}$ in diameter.

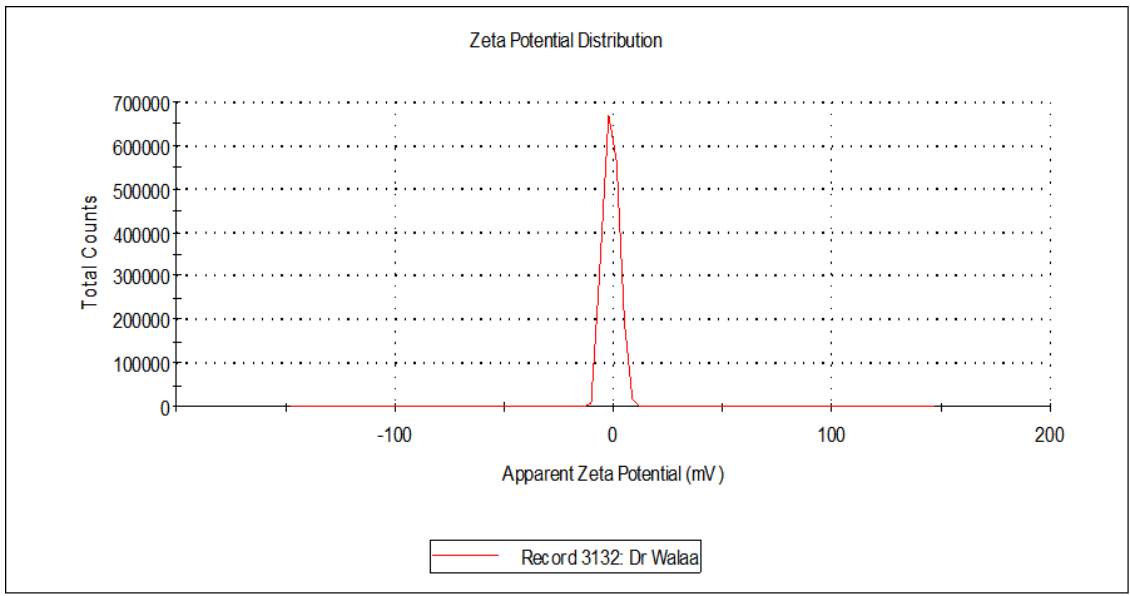

Figure (2): Zeta potential distribution of basil oil nanoemulsion exhibit a mean charge $-1.01 \mathrm{mV}$.

\section{Antimicrobial activity of basil oil nanoemulsion:}

\section{Antibacterial activity:-}

Results of Figure (3) showed that basil oil nanoemulsion had antibacterial effect against all examined bacterial isolates. Basil oil nanoemulsion at $0.006 \mathrm{ml}$ concentration gave an inhibition zones $20.5 \pm 2.7,16.66 \pm 1.2,21.33 \pm 1.3$ and $19.16 \pm 1.00 \mathrm{~mm}$ in diameter against Aeromonas hydrophila, Aeromonas veronii, Pseudomonas fluorescens 
and Streptococcus agalactiae, respectively. $0.003 \mathrm{ml}$ concentration of pure basil oil gave inhibition zones $13.5 \pm 2.02,22.00 \pm 1.00,15.83 \pm 2.3$ and $10.66 \pm 5.45 \mathrm{~mm}$ in diameter against Aeromonas hydrophila, Aeromonas veronii, Pseudomonas fluorescens and Streptococcus agalactiae respectively. Basil oil nanoemulsion had antibacterial effect in low doses than pure basil oil $(0.1 \mathrm{ml})$ against the examined bacterial isolates $13.5 \pm 2.02, \quad 22.00 \pm 1.00, \quad 15.83 \pm 2.3$ and $10.66 \pm 5.45 \mathrm{~mm}$ respectively.

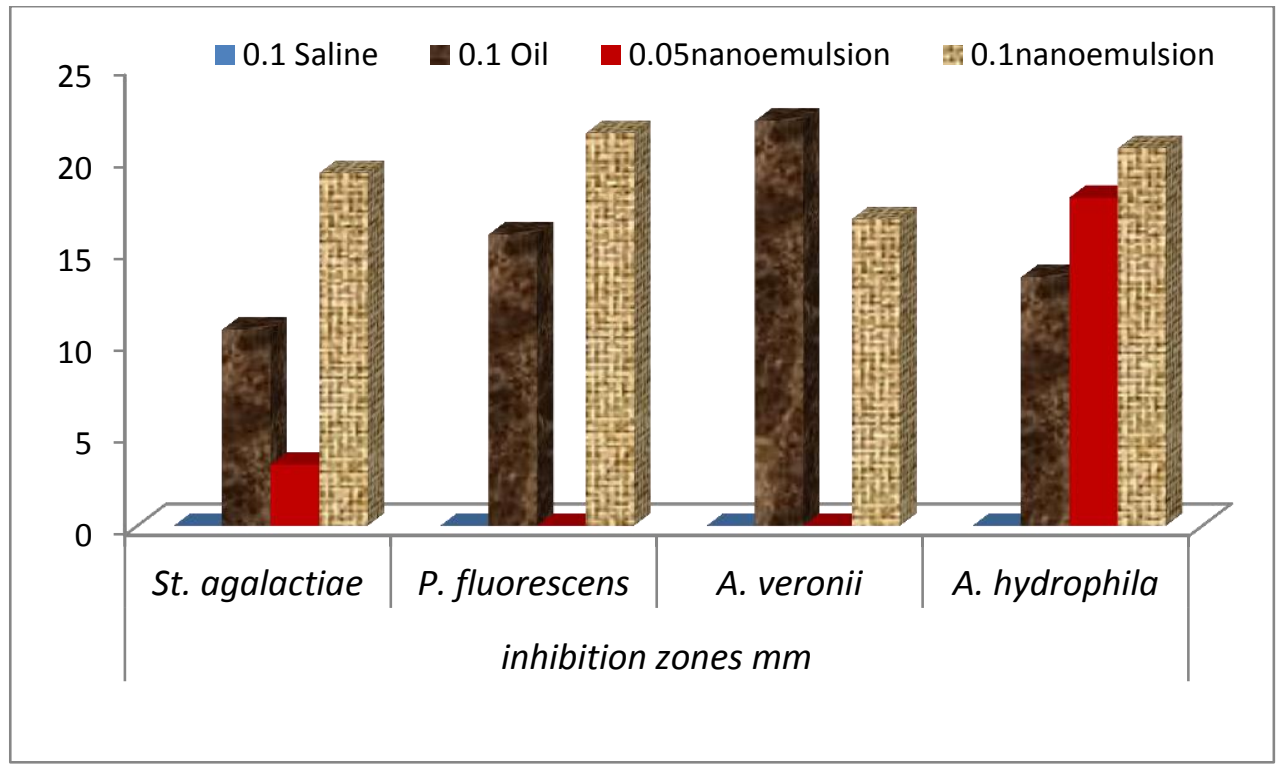

Figure (3): Inhibition zones of two doses of basil oil nanoemulsion $(0.003$ and $0.006 \mathrm{ml})$ and one dose of pure basil oil $(0.1 \mathrm{ml})$ against Aeromonas hydrophila, Aeromonas veronii, Pseudomonas fluorescens and Streptococcus agalactiae using disc diffusion method on Muller-Hinton agar. Pure basil oil used as control positive as $0.1 \mathrm{ml}$ and sterilized distilled water as control negative $0.1 \mathrm{ml}$.

\section{Antifungal activity:-}

From Figure (4) basil oil nanoemulasion at $0.003 \mathrm{ml}$ concentration had antifungal effect against Saprolegnia parasitica with inhibition zone $35.3 \pm 0.4 \mathrm{~mm}$. Pure basil oil and basil oil nanoemulsion at 0.1 and $0.006 \mathrm{ml}$ had no effect against Saprolegnia parasitica. 


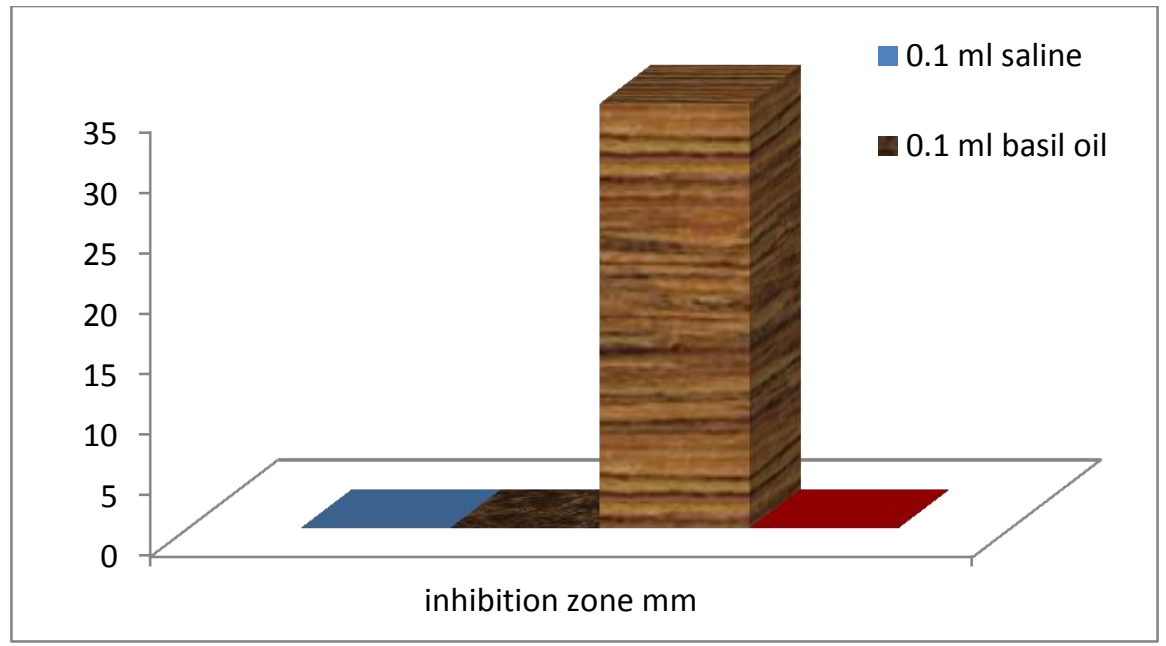

Figure (4): Inhibition zones of basil oil nanoemulsion at 50 and $100 \mu 1$ which contained 0.003 and $0.006 \mathrm{ml}$ concentration of pour basil oil against Saprolegnia parasitica on Sabouraud's Dextrose agar supplemented by Chloramphenicol (50 ppm). Pour basil oil used as control positive as $0.1 \mathrm{ml}$ and sterilized distilled water as control negative 0.1 $\mathrm{ml}$.

\section{Minimum inhibitory concentration (MIC):}

The results of MIC of basil oil nanoemulsion against the examined bacterial isolates (Aeromonas hydrophila, Aeromonas veronii, Pseudomonas fluorescens and Streptococcus agalactiae) were 3, 9, 9 and $9 \mu \mathrm{l}$ respectively as showed in Figure (5).

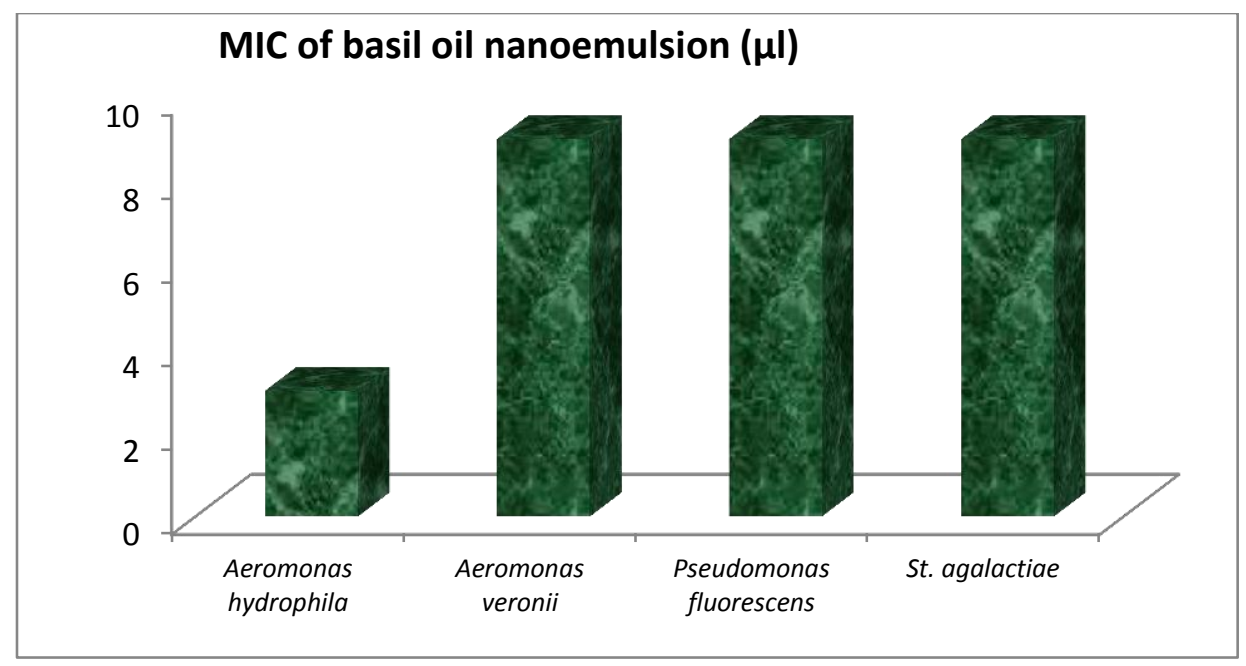

Figure (5): MIC of basil oil nanoemulsion against the examined bacterial isolates Aeromonas hydrophila, Aeromonas veronii, Pseudomonas fluorescens and Streptococcus agalactiae. 


\section{Mode of action of basil oil nanoemulsion against Aeromonas hydrophila by electron microscope:}

Transmission Electron Microscope (TEM) showed different actions of basil oil nanoemulsion against Aeromonase hydrophila incubated at $30^{\circ} \mathrm{C}$ for $18 \mathrm{~h}$. The non-treated control bacteria were intact and showed a smooth surface (Photo1and Photo3A) and the treated bacteria showed changes in cell structure due to the antagonistic effect of basil oil nanoemulsion such as pores formation in the cell wall and cell membrane of bacterial cell reached to a rupture and loss of cell wall. Other bacterial cell appeared partial lysis of internal bacterial cell contents to complete lysis (Photo 2, and Photo 3 B, C, D, E, F).
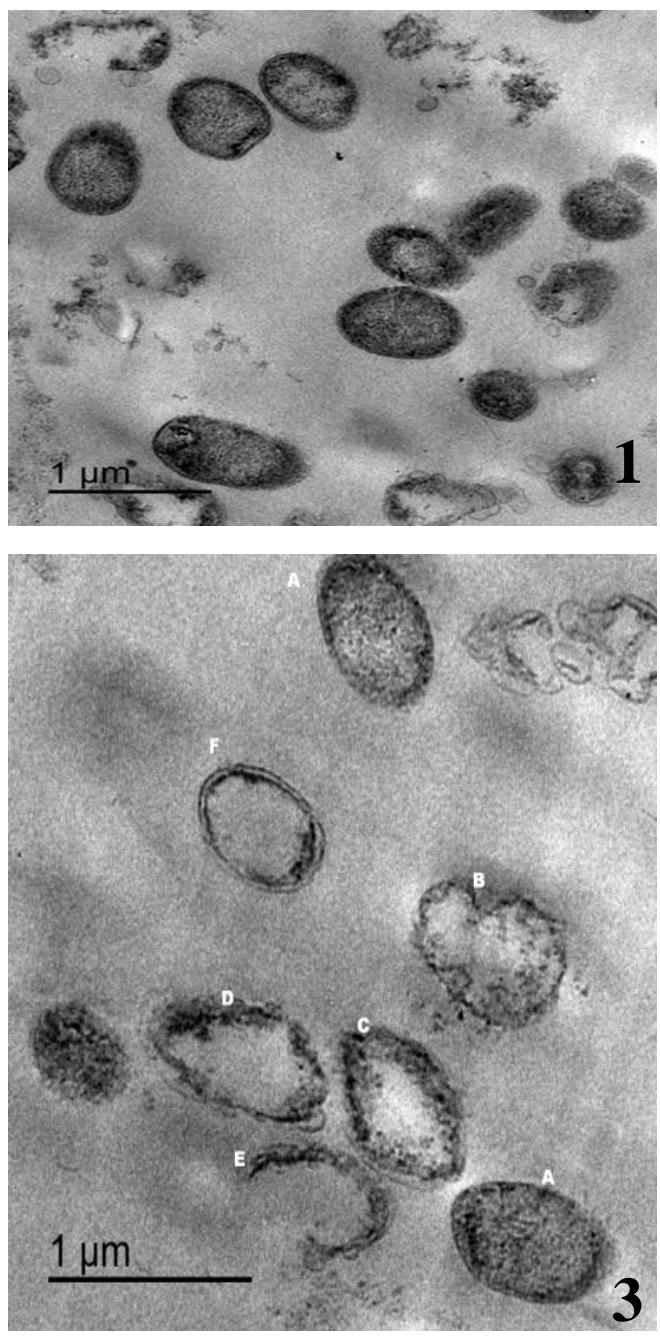

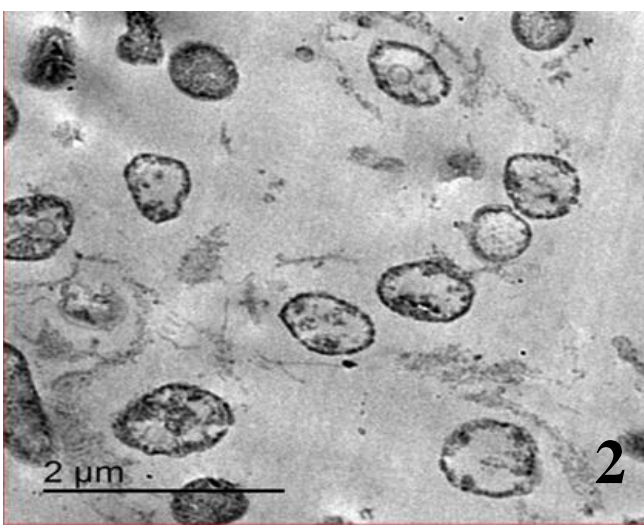

TEM micrographs of bacterial cells of A hydrophila showed 1-Control bacterial cells of $A$ hydrophila untreated with basil oil nanoemulsion (normal cells) 2-Bacterial cells of $A$ hydrophila treated with basil oil nanoemulsion. 3-Changes in bacterial cells of $A$ hydrophila A- Control bacterial cell of $A$ hydrophila untreated with basil oil nanoemulsion. B- Internally depression in the bacterial cell membrane with partially loss of the internal bacterial cell contents. C- Partially loss of bacterial cell wall with lyses of internal cell contents. D- Loss cell wall with pores in the cell membrane and lose of all internal bacterial cell contents. E- Rupture of cell wall and cell membrane with complete lyses of internal bacterial cell contents. FPores formation in the cell wall and cell membrane with complete loss of internal bacterial cell contents. 


\section{Safety of basil oil nanoemulsion for Oreochromis niloticus:}

Oreochromis niloticus fed diet contained basil oil nanoemulsion and diet free for 14 days had no abnormalities, morbidities or mortalities, so basil oil nanoemulsion save for $O$. niloticus at $8.5 \%$ of fish body weight.

\section{Challenge test:}

According to Figure (6) the mortality rate among fish group fed diet contained basil oil nanoemulsion was $6.3 \%$ while, control group (26.6\%).

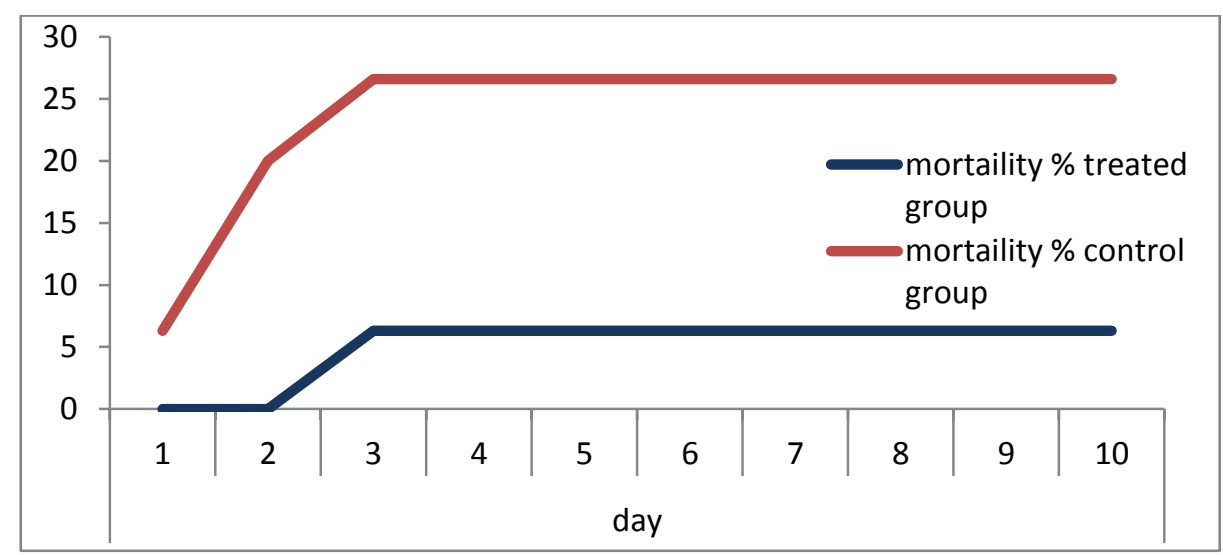

Figure (6): Mortality rate of fish groups fed diet supplemented with basil oil nanoemulsion and diet free for two weeks and challenged by emersion with live $A$. hydrophila.

\section{Relative Level of Protection}

From Figure (7) the Relative Level of Protection was high (74.4\%) in fish group fed diet supplemented basil oil nanoemulsion for two weeks and challenged with A. hydrophila. 


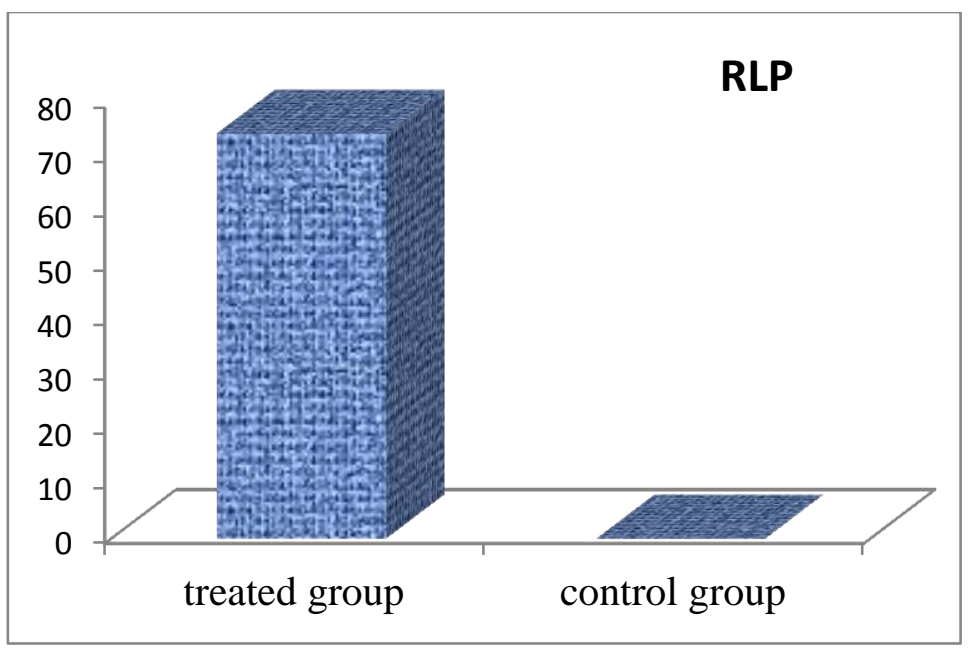

Figure (7): RLP in fish group fed diet supplemented with basil oil nanoemulsion for two weeks and challenged emersion with A. hydrophila.

\section{DISCUSSION}

In recent years, several scientific works have reported the use of nanoemulsions as suitable carriers of active essential oils. The preparation of nanoemulsion by the utilization of plant oils is cheap, readily scalable and environment-friendly. The nanoemulsions which are made up of different plant-based oils by the use of nonionic surfactant are very safe, biocompatible and having high stability Echeverría and Albuquerque (2019). Ocimum basilicum Linn., known as basil, belongs to the genus Ocimum (Lamiaceae), the Lamiaceae family, possess a wide range of biological and pharmacological activities with potential health beneficial effects Simon et al., (1990).

Characterization of the prepared basil oil nanoemulsion mean droplet size in this study was $6.419 \mathrm{~nm}$ proved that was less than $100 \mathrm{~nm}$, which means that was within the nano-range according to (McClements 2012 and Hassanin et al., 2017). PDI is a measure of the stability and uniformity of the droplet size in the nanoemulsion Anjali et al., (2010). The low PDI (0.753) of the formulated basil oil nanoemulsion indicates high uniformity of droplet size, a narrow size distribution and provide long-term stability to the formulated nanoemulsion, this stabilization is due to the presence of the surfactant that tends to help in the reduction of interfacial tension at oil/water interface leading to decrease in the free energy and thus provides a mechanical barrier to prevent accumulation of the droplets Mishra et al., (2014).Zeta potential, which was a measure of electrostatic potential at the electrical double layer surrounding 
a nanoparticle in solution, is generally determined to ascertain the electrical stability of nanoparticles in liquid suspensions. Nanoparticles with a zeta potential between -10 and $+10 \mathrm{mV}$ are considered approximately neutral Clogston and Patri (2011).Zeta potential of basil oil nanoemulsion was negative charge $1.01 \mathrm{mV}$ at $\mathrm{pH}$ of 5.55 ,these negative zeta potential values contribute for storage stability of nanoemulsion since the repulsive forces exceed attractive forces among droplets and such droplet-droplet repulsion prevents the coagulation and/or coalescence of dispersed phase of emulsions McClements (2012).Conductivity of the nanoemulsions was measured to determine the phase system (o/w or w/o) of the nanoemulsion Okur et al., (2011). Oil-in-water nanoemulsions were highly conducting because water is in the external phase. On the other hand, water-in-oil nanoemulsion, where water was in the internal phase less conducting Devarajan and Ravichandran (2011). From the conductivity results in this study the basil oil nanoemulsion was detected as oil-in-water nanoemulsions. The viscosity of basil oil nanoemulsion was $0.887 \mathrm{mpascal} / \mathrm{sec}$., the viscosity was very low. However, this coincides with one of the characteristics of nanoemulsion which is low viscosity Baboota et al. (2007).

Essential oils (EO) extracted from edible, therapeutic and herbal plants have been well recognized as natural antimicrobial, while nanoemulsions showed higher antibacterial efficacy as compared to the pure oil because of their increased surface area and small droplet size Pathania et al., (2018). Antimicrobial properties of nanoemulsion are believed to result from the small size of oil particles that have a high surface tension which can fuse with and subsequently disrupt the membrane of isolated prokaryotic cells, viruses, and eukaryotic cells of fungi but they do not affect eukaryotic cells of higher organisms.

In the present study, the basil oil nanoemulsion had antibacterial and antifungal effect against Aeromonas hydrophila, Aeromonas veronii, Pseudomonas fluorescens, Streptococcus agalactiae and Saprolegnia parasitica. MICs of basil oil nanoemulsion were 3, 9,9 and $9 \mu 1$ against the examined bacteria. Basil oil nanoemulsion exhibited antibacterial activity against all bacteria at the concentration of 3 and $6 \mu 1$. Also, exhibited a potent inhibitory effect against Aeromonas hydrophila, Aeromonas veronii, Pseudomonas fluorescens, Streptococcus agalactiae with diameters of inhibition zones. The antimicrobial activity of essential oils is due to their solubility in the phospholipids bilayer of cell membranes enable them to penetrate the cell walls of a bacterium or fungus Knobloch et al., (1989). Likewise, various chemical compounds 
and the individual principle constituents of basil essential oil (linalool,1,8- cineol and eugenol) which known to have antimicrobial activity. Pelczar (1993) suggested that linalool has the potential to act as either a protein denaturing agent or as a solvent dehydrating agent who may also contribute to its antimicrobial activity. Kim et al., (1982) studied the antibacterial activity of some essential oil components (including linalool and eugenol) against food-borne pathogens. They found that linalool and eugenol showed a dose-related increase in the zone of inhibition against the tested strains. From present results basil oil nanoemulsion was mainly bactericidal and bacteriostatic, this is due to the presence of eugenol as organic phenolic compound found in basil oil, which can denature proteins. Eugenol can react with phospholipids from cell membrane, and also it interacts with cell membrane permeability in a great number of bacteria and yeasts. Also basil oil nanoemulsion had antifungal activity against Saprolegnia parasitica at low dose $(3 \mu 1)$, while Hassanin et al., (2017) recorded that the growth inhibition of Fusarium oxysporum was linearly increased with an increase in concentration of by basil oil nanoemulsion. Ocimum basilicum has antifungal activity which also might be attributed to the presence of the main constituents (linalool and eugenol) compounds as reported by Oxenham et al., (2005). Antifungal action mechanisms of essential oils and their constituents are generally explained by membrane damage or disruption of its integrity, increasing permeability, inhibition of ergosterol synthesis or binding to ergosterol on the membrane and reactive oxygen species (ROS) production by acting on mitochondria Rajput and Karuppayil (2013). As well, ethanol, methanol and hexane are major constituents of Ocimum basilicum were investigated for their in vitro antimicrobial properties against 146 microbial organisms including aquaculture pathogens. They showed a stronger and broader spectrum of antibacterial activity and successfully controlled the pathogens, Aspergillus flavus and Fusarium oxysporum Adigu“zel et al., (2005). Our results compatible with Aboul Ela et al., (1996) who showed that basil essential oil has antibacterial and antifungal activity where linalool, is active against the tested microorganisms, potentially acting as either a protein denaturating agent or as a solvent dehydrating agent.

It is well known that essential oils and their components have activity against a variety of targets, particularly the membrane and cytoplasm, and in some cases, they completely change the morphology of the cells Nazzaro (2013). In this study basil oil nanoemulsion had more than one mode of action against Aeromonas hydrophila cells by inhibiting 
bacterial growth or killing bacterial cells. The emulsion made pours in the cell wall which increased permeability with partial or complete lysis of internal cell contents. These actions against bacterial cells may be due to different active compounds in basil oil which work through inhibition of different cellular biotic functions including ion leakage from the cells and disrupting the plasma membrane permeability Walsh et al., (2003). From another point of view this action may be due to essential oils hydrophobic tension, which allows them to penetrate microbial cells and cause disruption of the cell wall/membranes structure and impairment of cell functions leading to increase in the permeability bacterial cell membranes Nazzaro et al., (2013). The antibacterial active principles of the herbals may lyse the cell wall, block the protein synthesis and DNA synthesis, inhibit the enzyme secretions.

In current work basil oil nanoemulsion had antimicrobial at low doses but it was safe to Oerochromis niloticus at $8.5 \%$ supplemented diet and fed for 14 days and increased relative level of protection against A. hydrophila at the experimental infection. El-Ashram et al., (2017) mentioned that basil oil activated the immune system of the Nile tilapia and it became resistance to pathogenic bacteria. Wannissorn et al., (2005) reported that $O$. basilicum essential oil showed moderate antibacterial activity and Abasalh and Mohammad (2010) mentioned that $O$. basilicum enhanced the bactericidal activity.

\section{Conclusion}

It can be concluded that nanoemulsion of Ocimum basilicum oil can be used as natural antimicrobial agent, it had potent antibacterial activity against various strains of bacterial pathogen, antifungal effect against Saprolegnia parasitica and enhance fish resistant against Aeromonas hydrophila, in addition it is safe to be used in aquaculture system.

\section{REFERENCES}

Abasalh, H. and Mohammad, S. (2010). Immunostimulants diets. Journal of Animal and Veterinary Advances. 9(13), 1839-1847.

Abbas, K., Abdulkarim, S., Saleh, A. and Ebrahimian, M. (2010). Suitability of viscosity measurement methods for liquid food variety and applicability in food industry - A review Journal of Food, Agriculture \& Environment, 8(3\&4): 100-107.

Aboul Ela, M.A., El Shaer, N.S., Ghanem, N.B. (1996). Antimicrobial evaluation and chromatographic analysis of some essential and fixed oils. Pharmazie 51(12): 993-994. 
Adigu"zel, A., Medine, G., Meryem, B., Hatice, U.T.C., Fikrettin, A., U“sa, K. (2005) Antimicrobial effects of Ocimum basilicum (Labiatae) extract. Turk J Biol 29:155-160.

Angioni, A., Barra, A., Coroneo, V., Dessi, S., Cabras, P., (2006). Chemical composition, seasonal variability, and antifungal activity of Lavandula stoechas L. ssp. Stoec has essential oils from stem/leaves and flowers. J. Agric. Food Chem. 54, 4364-4370.

Anjali, C., Khan, S., Goshen, K. and Magdassi, S. (2010). Formulation of water-dispersible nanopermethrin for larvicidal applications. Ecotoxicology and Environmental Safety., 73: 1932-1936.

Baboota, S., Alazaki, A. Kohli, K., Ali, J., Dixit, N. and Shakeel, F. (2007). Development and evaluation of a microemulsion formulation for transdermal delivery of terbinafine. PDA J. Pharm. Sci. Technol., vol. 61, no. 4, pp. 276-285.

Citarasu, T. (2010). Herbal biomedicines: a new opportunity for aquaculture industry. Aquaculture International 18: 403-414.

Clogston, J.D. and Patri, A.K., 2011. Zeta potential measurement. Methods Mol. Biol. 697,63-70.

Devarajan, V. and Ravichandran, V. (2011). Nanoemulsions: as modified drug delivery tool. International Journal of Comprehensive Pharmacy, vol. 2, no. 4, pp.1-6.

Dytham, C., (1999). Choosing and using statistics: A Biologist's guide Blackwell Science Ltd., London, United Kingdom, p. 147.

Echeverría, J. and Albuquerque, R.D.D.G.(2019). Nanoemulsions of Essential Oils: New Tool for Control of Vector-Borne Diseases and In Vitro Effects on Some Parasitic Agents. Medicines (MDPI) DOI:10.3390/medicines 6020042.

El-Ashram, A. M.M., Afifi, A A.M. and Sakr, S. F.(2017). Effect of basil oil (Ocimum basilicum) on nonspecific immune response of Nile-tilapia (Oreochromis niloticus).Egy. J. Aquac., Vol.7, No. (2):1531 (2017) ISSN: 2090-7877.

Ghosh, V., Mukherjee, A., and Chandrasekaran, N. (2013). Formulation and characterization of plant essential oil based Nanoemulsion: evaluation of its Larvicidal activity against Aedes egypti. Asian J. Chem., 25:S321-S323.

Hassanin, M.M.H., Abd-El-Sayed, M. A., Abdallah, M. A. (2017). Antifungal activity of some essential oil emulsions and nanoemulsions against Fusarium oxysporum pathogen affecting cumin and geranium 
plants scientific $\mathrm{j}$ of flowers and ornamental plants Volume 4, Issue 3, Page 245-258.

Jerbi, M.A., Ouanes, Z., Besbes, R., Achour, L., Kacem, A., (2011).

Single and combined genotoxic and cytotoxic effects of two xenobiotics widely used in intensive aquaculture. Mutat. Res.724, 2227.

Kim, J., Marshall, M.R., Wei, C. (1982). Antibacterial activity of some essential oil components against five foodborne pathogens. J. Agric. Food Chem. 43(11): 2839-2845.

Kinner, N. E., Balkwill, D. L. and Bishop, P. L. (1983). Light and electron microscopic studies of microorganisms growing in rotating biological contactor biofilms. Applied and Environmental Microbiology, Vol. 45, No. 5.pp. 1659-1669.

Knobloch, K., Pauli, A., Iberl, B., Weigand, H., Weis, N. (1989). Antibacterial and antifungal properties of essential oil components. J. Essent. Oil Res. 1: 118-119.

Madhuri, S., Maheshwar, S., Sunil, P. and Oza, G. (2012). Nanotechnology: concepts and applications, vol 4. CRC Press, USA.

Malik, P., Shankar, R., Malik, V., Sharma, N. and Mukherjee, T.K. (2014). Green chemistry based benign routes for nanoparticle synthesis. J. Nanopar.Vol.2014:14. doi: 10.1155/2014/302429.

McClements, D. J. (2012). Nanoemulsions versus microemulsions: terminology, differences, and similarities. Soft Matter 8, 1719-1729.

Mishra, P., Suresh Kumar, R.S., Jerobin, J., Thomas, J., Mukherjee, A. and Chandrasekaran, N. (2014). Study on antimicrobial potential of neem oil nanoemulsion against Pseudomonas aeruginosa infection in Labeorohita. Biotechnol. Appl. Biochem. 61(5):611-619.

Murray, P.R., Baron, E.J., Pfaller, M.A., Tenover, F.C., Yolken, H.R.(2007). Manual of Clinical Microbiology 9th ed. ASM Press: Washington; D.C: $1152-1172$.

Nazzaro, F., Fratianni, F., De Martino, L., Coppola, R., De Feo, V. (2013). Effect of essential oils on pathogenic bacteria. Pharmaceuticals. 6(12):1451-1474.

NCCLS.(2004). National Committee for Clinical Laboratory Standards. Performance Standards for Antimicrobial Disk and Dilution Susceptibility Tests for Bacteria: Approved Standard M31-A2. Wayne, Pa. 
Okur, N. U., Apaydin, S., Yavaşoğlu, N. Ü., Yavaşoğlu, K. A. and Karasulu, H. Y.(2011). Evaluation of skin permeation and antiinflammatory and analgesic effects of new naproxen microemulsion formulations. International Journal of Pharmaceutics, vol. 416, no. 1, pp. 136-144.

Oxenham, S.K., Svoboda, K.P. and Walters, D.R. (2005): Antifungal Activity of the Essential Oil of Basil (Ocimum basilicum). J. Phytopathol., 153: 174-180.

Pathania, R., Khan, H., Kaushik, R. and Khan, M. A. (2018). Essential Oil Nanoemulsions and their Antimicrobial and Food Applications. Curr. Res. Nutr Food Sci Jour., Vol. 6(3), 626-643.

Pelczar ,M.J., Chan, E.C.S., Krieg, N.R. (1993). Control of microorganism: Chemical agents. In Microbiology: Concepts and Applications. McGraw-Hill: New York, USA, pp. 221- 241.

Rajput, S.B. and Karuppayil, S.M. (2013): Small molecules inhibit growth, viability and ergosterol biosynthesis in Candida albicans, Springerplus 2, 26.

Ruangroupan, L., Kitao, T. and Yoshida, T. (1986). Protective efficacy of Aeromonas hydrophila vaccines in Nile tilapia. Veterinary Immunology and Immunopathology 12(1-4):345-350.

Salager J. L., Antón R.E., Andérez J.M., Aubry J.M. (2001). Techniques de l'Ingénieur. 1st ed. Editions T.I.; Paris, France. Formulation des micro-émulsionspar la méthode HLD; pp. 1-20.

Shafiq, S., Faiyaz, S., Sushma, T., Farhan, J., Khar, R. and Ali, M. (2007). Design and development of ramipril nanoemulsion formulation: in vitro and in vivo assessment. J. Biomed Nanotechnol., 3:28-44.

Simon, J.E., Quinn, J., Murray, R.G. (1990). Basil: a source of essential oils. In Janick J. and Simonyi J.E. (eds.) Advances in new crops. Portland: Timber Press.

Sugumar, S., Clarke, S., Nirmala, M., Tyagi, B., Mukherjee, A., and Chandrasekaran, N. (2014). Nanoemulsion of eucalyptus oil and its larvicidal activity against Culex quinquefasciatus. Bull Entomol Res.,104(03): 393-402.

Suresh, R. S., Shiny, P. J., Anjali, C. H, Jerobin, J., Goshan, K. M., Magdasi, S. Mukherjee, A. and Chandrasekaran, N. (2013Distinctive effects of nano-sized permethrin in the environment Sci. Pollut. Res. 20, 2593-2602. 
Syahidah A.; Saad C.R.; Daud H.M.; Abdelhadi Y.M. (2015). Status and potential of herbal applications in aquaculture: A review. Iranian Journal of Fisheries Sciences 14(1) 27-44.

Walsh, S.E., Maillard, J.Y., Russell, A.D., Catrenich, C.E., Charbonneau, D.L. (2003). Activity and mechanisms of action of selected biocidal agents on Gram-positive and -negative bacteria. J Applied Microbiol 94: 240-247.

Wannissorn, B., S., Jarikasem, T., Siriwangehaiand and S. Thubthimthed, 2005. Antibacterial properties of essential oils from Thai medicinal plants. Fitoterapia, 76: 233-236.

Yu, J.Q., Lei, J.C., Yu, H., Cai, X. and Zou, G.L. (2004). Chemical composition and antimicrobial activity of the essential oil of Scutellaria barbata. Phytochemistry 65, 881-884. 


\section{تقييم مستحلب النانو لزيت الريحان كمثبط للميكروبات و زيادة مقاومة أسماك الكائ

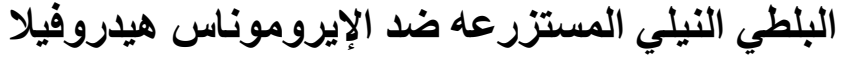 \\ ولاء طلعت الإكيابى}

قسم بحوث صحة الأسماك ور عايتها ـالمعل المركزى لبحوث الثروة السمكية_ مركز البحوث

$$
\text { الزراعية - مصر المرك ليحس العربى }
$$

تم معالجها زيت الريحـان النقي ذات التاثثر المضـاد للميكروبـات و المحفز للمناعه في الأسماك

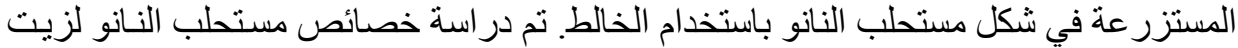

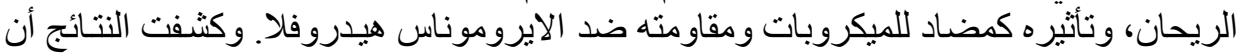

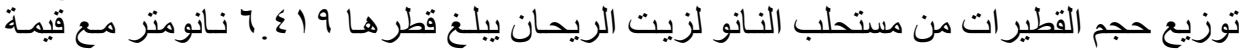

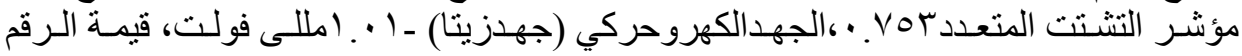

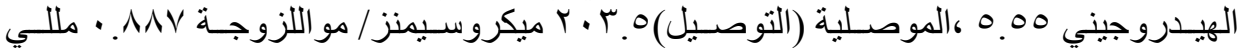

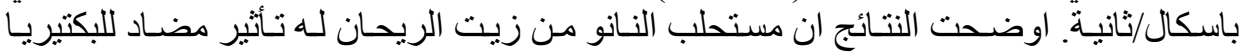

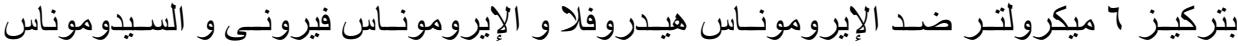

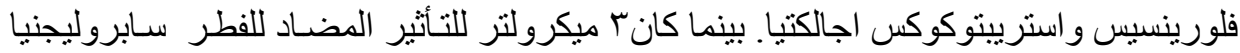

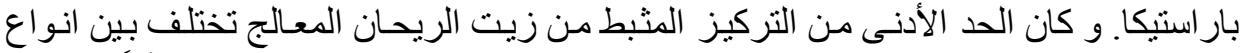

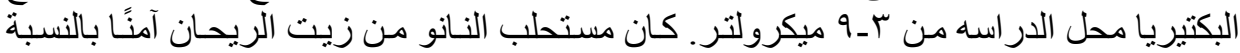

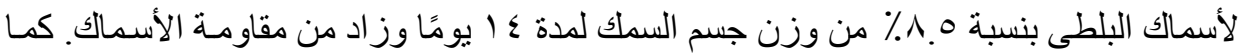

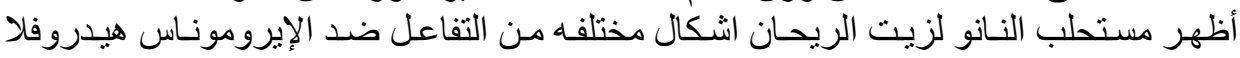
بإستخدام المجهر الإلكتروني التى تمت مناقتشها في هذه الدراسه. 